\title{
A New Paradigm to Mitigate Osteosarcoma by Regulation of MicroRNAs and Suppression of the NF-kB Signaling Cascade
}

\author{
Raj Kumar Mongre ${ }^{1}$, Simrinder Singh Sodhi ${ }^{1}$, Mrinmoy Ghosh ${ }^{1}$, Jeong Hyun Kim ${ }^{1}$, Nameun Kim ${ }^{1}$, \\ Neelesh Sharma ${ }^{2}$ and ${ }^{\dagger}$ Dong Kee Jeong ${ }^{1}$ \\ ${ }^{I}$ Laboratory of Animal Genetic Engineering and Stem Cell Biology, Dept. of Animal Biotechnology, \\ Faculty of Biotechnology, Jeju National University, Jeju 690-756, Korea \\ ${ }^{2}$ Division of Veterinary Medicine, Faculty of Veterinary Science \& Animal Husbandry, \\ Sher-e-kashmir University of Agricultural Sciences \& Technology of Jammu, R.S. Pura, Jammu, India
}

\begin{abstract}
Osteosarcoma (OS) is one of the most common malignant primary bone tumors and NF- $\kappa \mathrm{B}$ appears to play a causative role, but the mechanisms are poorly understood. OS is one of the pleomorphic, highly metastasized and invasive neoplasm which is capable to generate osteoid, osteoclast and osteoblast matrix. Its high incidence has been reported in adolescent and children. Cell signal cascade is the pivotal functional mechanism acquired during the differentiation, proliferation, growth and survival of the cells in neoplasm including OS. The major limitation to the success of chemotherapy in OS is the development of multidrug resistance (MDR). Answers to all such queries might come from the knock-in experiments in which the combined approach of miRNAs with NF- $\kappa B$ pathway is put into use. Abnormal miRNAs can modulate several epigenetical switching as a hallmark of number of diseases via different cell signaling. Studies on miRNAs have opened up the new avenues for both the diagnosis and treatment of cancers including OS. Collectively, through the present study an attempt has been made to establish a new systematic approach for the investigation of microRNAs, biophysiological factors and their target pairs with NF- $\kappa B$ to ameliorate oncogenesis with the "bridge between miRNAs and NF$\kappa \mathrm{B}$ ". The application of NF- $\kappa \mathrm{B}$ inhibitors in combination with miRNAs is expected to result in a more efficient killing of the cancer stem cells and a slower or less likely recurrence of cancer.
\end{abstract}

Key words : Targetome, GWAS, BBNM, Histeotypic neoplasia, RANK, miR

\section{INTRODUCTION}

Histiotypic neoplasia in Osteosarcoma (OS) is one of the most common malignant primary bone tumor specifically in the bones of fore limb, hind limb and metaphysical region of long bones (Longhi et al., 2006; Vigorita, 2008). Damage to the interconnecting soft tissues is a major concern with such kind of tumors (Vigorita, 2008). It is one of the highly metastasized cellular tumors with pleomorphic spindleshaped cells. These spindle shaped cells are involved in the efficient generation of an osteoid, osteoclast and osteoblast matrix and very well histologically characterize the OS (Vigorita, 2008). It is reported to have high incidence in adolescents and young ones. $60-70 \%$ of survival rate up to

\footnotetext{
Manuscript received 4 November 2014, Received in revised form 12 November 2014, Accepted 13 November 2014

${ }^{\dagger}$ Corresponding Author : Dong Kee Jeong, Laboratory of Animal Genetic Engineering and Stem Cell Biology, Dept. of Animal Biotechnology, Faculty of Biotechnology, Jeju National University, Jeju 690-756, Korea. Mobile : +82-10-8713-8045, Tel. : +82-64-754-3331, Fax : +82-64-725-2403-3331, Email : dkjeong@jejunu.ac.kr

This is an Open Access article distributed under the terms of the Creative Commons Attribution Non-Commercial License (http:// creativecommons.org/licenses/by-nc/3.0) which permits unrestricted non-commercial use, distribution, and reproduction in any medium, provided the original work is properly cited.
} 
five years after diagnosis has been reported in the patients with $8.9 \%$ mortality in children (Longhi et al., 2006). OS is reported to have moderate morbidity (10 to 26 cases/ million/year) (Stiller, 2007). The metastasized cells most often spread to the lungs, bones and brain (Longhi et al., 2006). The multi-agent approach involves chemotherapy, surgery and radiation but it is not fully adequate to eliminate OS (ACS, 2013). Longhi et al. (2006) and NIH (2014) reported, prototype OS manifests few frequent traits like growth rate, cell division with aggression and early pulmonary metastases. Furthermore, Karlsson et al. (2013) reported 33 high inheritable loci for OS in multiple dog breed by genome-wide association study (GWAS). Collectively, these data show the dire need of an essential innovative drugs and approaches to further improve the prognosis of OS patients.

Bio-signal trafficking is the pivotal functional mechanism acquired in the differentiation, proliferation, growth and survival of the cells (Lin \& Liu, 2008). During histeotypic neoplasia normal cells follow altered ways to proliferate independently due to growth promoting conditions (Iliopoulos et al., 2009). At the same time, growth inhibitory signals with respect to metastasis, elicit an angiogenic responses as well as to evade mechanism that arrest cell growth cycle and proliferation (Martin, 2003). Inhibition of kappa B kinase blocks the induction of nuclear factor-kappaB (NF$\kappa \mathrm{B})$ signaling and makes bridge between inflammation and cancer (Lin \& Liu, 2008; Oeckinghaus et al., 2011). Ghosh $\&$ Karin, (2002) reported regulation of the wide variety of genes encoding cytokines (e.g., IL-1, IL-2, IL-6, IL-12, TNF- $\alpha$, LT $\alpha$, LT $\beta$ and GM-CSF), chemokines (e.g., IL-8, MIP-1 $\alpha$, MCP1, RANTES and eotaxin), adhesion molecules (e.g., ICAM, VCAM and E-selectin) acute phase proteins (e.g., SAA) and inducible effector enzymes (e.g., iNOS

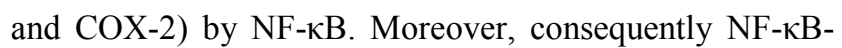
dependent transcription is not only tightly controlled by positive and negative regulatory mechanisms but also closely coordinated with other signaling pathways such as JNK, Akt and MAPK (Baker et al., 2011; Oeckinghaus et al., 2011).

Small non-coding microRNA (miRNA) is a primary regulator of signal trafficking processes which modulate bio-physiological activities such as developmental timing, proliferation, cell metabolism, differentiation and cell apoptotic activity (Mendell \& Olson, 2012). The modulation takes place by the suppression of several candidate genes during transcription and post-translation on the basis of ambiance. The abnormal expression of miRNA observed in number of cancer patients presents miRNA as candidates targets for the therapeutic intervention of neoplasm including OS (Mitchell et al., 2008; Davis \& Hata, 2009). The transcriptional regulation of miRNAs occurs near the intron region of protein coding and non-coding genes by their host gene promoter. It is also reported that RNA-induced silencing Complex (RISC) negatively suppresses the gene expression of targeted mRNA through the $3^{\prime}$ untranslated region (3' UTR) (Davis \& Hata, 2009). The miRNA plays a dual role in cancer biology. It can either induce or suppress the proliferation or both (Esquela-Kerscher \& Slack, 2006). The miRNA works as potential biomarkers and therapeutic targets in different sarcoma including OS (Ouyang et al., 2013). Furthermore, the miRNA based approaches for eradication and diagnosis of OS can be handled in two strategic ways (Kobayashi et al., 2012) i.e. to inhibit the expression of oncogenic miRNA using antisense oligonucleotides (anti-miR) and secondly to induce the expression level of tumor suppressor miRNAs by inserting miRNA mimics (Esquela-Kerscher \& Slack, 2006; Shimada, 2013). A noble approach of study has revealed by Poos et al. (2013) that miRNAs and transcription factors (TFs) are master regulators of the biological systems. In contrast, miRNAs and TFs together make mega diverse network to have desired action and finally results in distinct cellular phenotype. It is reported here that several genes, TFs, and 
miRNAs form co-regulatory network in OS cell growth as one hallmark in cancer (Poos et al., 2013). Therefore, at this point the understanding of the role and mode of action of miRNAs is need of hour.

In this study, an attempt has been made to correlate several miRNAs with different factors of nuclear factor of kappa B (NF-kB). A novel bridge model between "miRNAs and NF- $\kappa$ B" has been proposed in the current study to have an efficient control of the OS. The miRNA profiling of primary tumors has prognostic value for the survival rate and it targets the beneficiary results for OS patients who previously had third to sixth-line treatment with antiepidermal growth factor receptor (EGFR) based therapy.

\section{NF- $\kappa B$ VERSUS THE IKB FAMILY AS MASTER REGULATOR}

NF- $\kappa \mathrm{B}$ plays a central role in the regulation of diverse biological processes, including immune responses, development, cell proliferation and survival (Esquela-Kerscher \& Slack, 2006; Perkins, 2007). At the same time deregulated $\mathrm{NF}-\kappa \mathrm{B}$ has been linked to a variety of human diseases; in particular cancers (Perkins, 2007; Karin, 2009). The NF$\kappa \mathrm{B}$, a transcriptional regulator consists of reticuloendotheliosis (Rel) protein dimers and binds with a DNA sequence motif known as $\kappa \mathrm{B}$ site (Huxford \& Ghosh, 2009). Depending upon their requirement for proteolytic processing the Rel protein family is classified into two groups (Huxford \& Ghosh, 2009). The Rel proteins which require proteolytic processing includes NF- $\mathrm{kB} 1$ (also known as p105) and NF-кB2 (p100), which are processed to produce the mature p50 and p52 proteins, respectively (Fig. 1). The Rel protein without proteolytic processing includes Rel A (also known as p65), Rel-B and Rel-C. NF- $\mathrm{B}$ signal cascade involves canonical and non-canonical pathways (Sun, 2011). It is worth mentioning over here that canonical pathway induced by extracellular factors includes tumor necrosis factor $\alpha(\mathrm{TNF}-\alpha)$ and Interlukin-1 (IL-1) those activate NF-kappa-B essential modulator (NEMO) (Oeckinghaus et al., 2011). Further it has been reported that NEMO makes complex with Inhibitor kappa kinase (IKK) $\alpha / \beta$ and p50/ RelA to phosphorylate the Inhibitor of kappa B alpha $(\mathrm{IkB} \alpha)$. Later, phosphorylated p50/RelA translocates to nucleous to activate target genes (Ghosh \& Karin, 2002). Similarly, Lipopolysacharide (LPS) and CD40L are reported to activate NF-inducing kinase (NIK) to initiate noncanonical pathway by involving IKK $\alpha / \beta$, p100, RelB complex and phosphorylated p100 activate RelB/p52 (Sun, 2011) which translocate to nucleous and interact with target $\kappa \mathrm{B}$ element and regulate transcription (Lin et al., 1998). Receptor activator of nuclear factor kappa-B kinase (RANK) in osteoclast formation and bone remodeling via TRAF, regulate seven different signaling pathways including four directly (IKK-NF-кB, JNK1, Myc, calcineurin-NFAT mediate osteoclastogenesis), two (Src-Akt, p38) by osteoclast activity and two other promote osteoclast survival via SrcAkt and Erk1/2 (Beristain et al., 2012).

All known NF- $\kappa \mathrm{B}$ activators converge toward the IKK complex to activate the canonical and non-canonical NF$\kappa \mathrm{B}$ pathways (Sun, 2011). The IKK complex contains two catalytic (IKK $\alpha$ and IKK $\beta$ ) and a regulatory subunit (NEMO/IKK $\gamma)$ which those regulate the canonical NF- $\kappa \mathrm{B}$ pathway, whereas IKK $\alpha$ regulates the non-canonical pathway (Oeckinghaus et al., 2011). The process of IKK $\alpha$ activation and its role in the regulation of canonical NF- $\kappa \mathrm{B}$ activation remain elusive (Hoesel \& Schmid, 2013). In the canonical $\mathrm{NF}-\kappa \mathrm{B}$ signaling pathway, stimuli such as tumor necrosis factor $\alpha(\mathrm{TNF} \alpha)$ recognition by the TNF receptor leads to activation of the inhibitor of IkBa kinase (IKK). IKK then phosphorylates $\mathrm{I} \kappa \mathrm{B} \alpha$, which results in K48-linked polyubiquitination of I $\mathrm{I} \mathrm{B} \alpha$ followed by proteasome-dependent degradation (Oeckinghaus et al., 2011). It can regulate the Raf-1 kinase inhibitor protein (RKIP) by the down regulation of zink finger protein (SNAIL) during the cytotoxic T-cell 


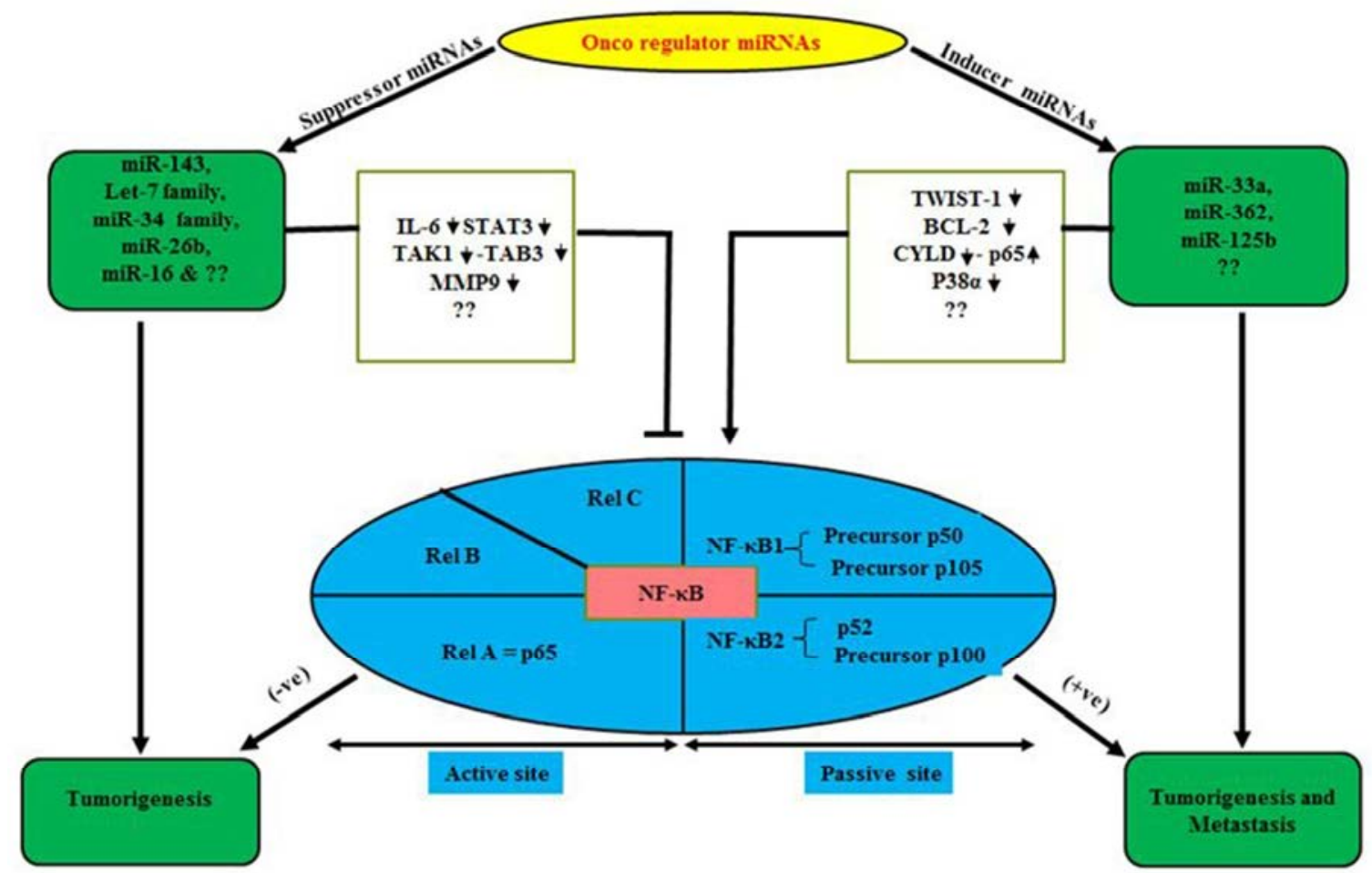

Fig. 1. A bridging avenue to ameliorate oncogenesis through miRNAs and NF- $\mathbf{k B}$. A diagrammatic representation of a bridging process depicting relation of suppressor and inducer miRNAs with NF- $\kappa \mathrm{B}$ as BBMN in neoplasia.

response to viral infection and/or cancer in cells expressing the resistant NF-kappaB-Snail-RKIP phenotype (Fig. 2) (Baritaki \& Bonavida, 2010). Moreover, Ubiquitin is a small protein that exists in all eukaryotic cells where it can attach to lysine residues of substrate protein in posttranslational modification with the help of E1s, E2s and E3s enzymes to form Lysine 48-linked chains to proteasome that degrade and recycle the unwanted proteins (Rieser et al., 2013). Furthermore, NF-кB can be downregulated by cysteine methylation mediated disruption of Ubiquitin chain via $E$. coli NIeE, S-adenosyl-L-methionine-dependent methyltransferase activity in the the Np14 zinc finger (NZF) domains in TAB2 and TAB3 (Zhang et al., 2012). The IKK family and their regulatory subunit NF-kappa-B are essential modulators (NEMO, also known as IKK- $\gamma$ ) which have ubiquitin-binding domain that binds to polyubiquitin chains to form a huge complex. It facilitates the interaction between IKK $\beta$ and its kinase TGF- $\beta$-activated kinase $(\mathrm{Wu}$ et al., 2006). In case of Crohn's disease, nucleotide-binding oligomerization domain-containing protein 2 (NOD2) is reported to induce $\mathrm{NF}-\kappa \mathrm{B}$ activation via K63-linked ubiquitin conjugation to NEMO (Abbott et al., 2004). The human protein HSCARG (also termed as NmrA-like family domain containing 1), several Deubiquitinases (DUBs), protein A20, cylindromatosis gene (CYLD), Ubiquitin specific proteases 7 (USP7) and several unknown enzymes interact to form complex which can inhibit the NEMO polyubiquitination. Inhibition of NEMO polyubiquitination is reported to decrease proteasomal degradation of $\mathrm{I} \kappa \mathrm{B} \alpha(\mathrm{Li}$ et al., 2014), which retains NF- $\kappa B$ in the cytoplasm. This complex further suppresses NF- $\kappa \mathrm{B}$ activity (Fig. 2) (Pujari et al., 2013). Oeckinghaus et al. (2011) reported the activation of NF- $\kappa \mathrm{B}$ via the binding of a ligand e.g., TNF $\alpha$, IL-1, TNF superfamily of molecule ligand (CD40L). Conjugation of LPS to its receptors is also reported to activate binding of TNF receptor type 1-associated DEATH domain (TRADD) 


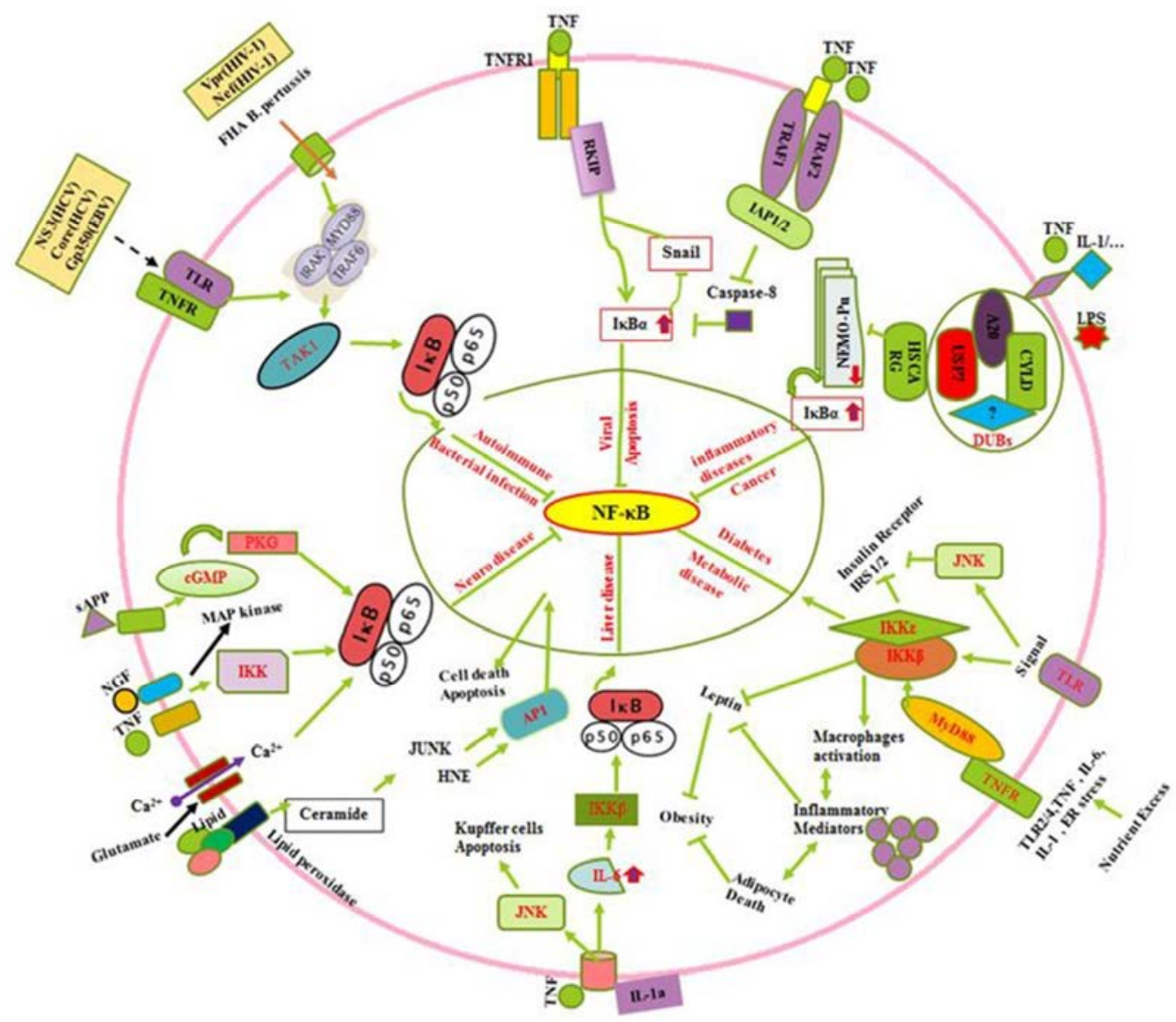

Fig. 2. Crosstalk between NF-кB and various biochemical regulators in different cellular processes as a master key regulator. Interaction of several stress ligands, proteneous extracellular factors inducing signaling cascade and inhibition of Kappa kinase complex in metabolic, inflammatory, neuronal, cancer and infection immune diseases have been depicted to explain the role of NF- $\mathrm{KB}$ cascade.

to TNF receptor-associated factor $2 /$ Receptor-interacting serine/threonine-protein kinase 1 (TRAF2/RIP1) (Solt et al., 2007). It further triggers a series of events involving signaling cascade (Fig. 2) through phosphorilisation of IKK $\alpha / \beta$ (Lin et al., 1998). The activation of NF- $\kappa B$ by $\mathrm{TNF} \alpha$ is strongly linked with the inhibition of apoptosis due to the ability of $\mathrm{NF}-\kappa \mathrm{B}$ to regulate expression of antiapoptotic genes such as TRAF1, TRAF2, c-IAP1, cIAP2, Bcl-2, and Bfl-1/A1 via suppression of Caspase-8 (Fig. 2) (Wang et al., 1998). In addition, extracellular factors including TNF, NGF, sAPP, lipids and minerals such as $\mathrm{Ca}^{2+}$ up regulates the I $\kappa \mathrm{B} \alpha$ by IKK activation (Mattson \& Camandola, 2001), by induced cyclic GMP that activate cGMP-dependent protein kinase (PKG) in neuronal abnormalities (Fig. 2). Collectively, it is observed that diverse signals (TNF- $\alpha, \operatorname{sAPP} \alpha, \mathrm{NGF}$, glutamate, increase in levels of intracellular $\mathrm{Ca}^{2+}$ and reactive oxygen species such as $\mathrm{H}_{2} \mathrm{O}_{2}$ ) can suppress NF- $\kappa \mathrm{B}$ activation via phosphorilization of $\mathrm{I} \kappa \mathrm{B} \alpha$ (Mattson \& Camandola, 2001; Kaltschmidt et al., 2005; Kaltschmidt \& Kaltschmidt. 2009). Several signal (prostate apoptosis response-4 $\{$ Par- 4$\}$ and the lipid peroxidation product 4-hydroxynonenal $\{\mathrm{HNE}\}$ ) those inhibit $\mathrm{NF}-\kappa \mathrm{B}$ activity is generated in neurons undergoing apoptosis (Mattson \& Camandola, 2001). NF$\kappa \mathrm{B}$ is modulated by signals (Fig. 2) emanated from activator protein-1(AP1), glucose-regulated protein-78 (GRP-78), Jun 
$\mathrm{NH}_{2}$-terminal kinase (JUNK), cyclic guanosine monophosphate (cGMP)-dependent protein kinases (PKGs) and cGMPdependent protein kinase (Mattson \& Camandola, 2001). Moreover, TLR2/4, TNF, IL-6, IL-1 and endoplasmic reticulum (ER) stress during metabolic imbalance show insulin resistance which later activate cytokine inflammatory as well as insulin regulating trafficking by Toll-like and cytokine receptors through MyD88 (Baker et al., 2011). In addition the death domain adaptor molecules via TRAFs result in phosphorylation and activation of the IKK complex which control the diabetogenesis (Fig. 2) (Chen, 2005). It leads to activated macrophage production, inflammatory action that cause adipocyte death, suppression of Insulin receptor substrate $1 / 2$ (IRS-1/2), inhibition the leptin and negatively control the obesity (Baker et al., 2011). In early stages of tumorigenesis or viral infection, the cytoprotective effect of NF- $\kappa \mathrm{B}$ is beneficial because it prevents hepatocyte cell death, and thus avoiding the release of IL-1a by necrotic hepatocytes and the triggering of compensatory proliferation (Sun \& Karin, 2008). In late stages of tumorigenesis, Papa et al. (2009) suggested that $\mathrm{NF}-\kappa \mathrm{B}$ supports malignancy by promoting the survival of the transformed hepatocytes against the JNK mediated injury and cell death. In non-parenchymal cells of the liver, NF- $\kappa \mathrm{B}$ activation during all stages of hepato-carcinogenesis is detrimental because it provides the emerging and growing hepatoma cells with essential growth factors, allowing them to proliferate (Sakuda et al., 2002). In addition (Fig. 2) to oxidative stress, the excessive hepatocyte death in both IKK $\beta$ knockouts and IKK $\gamma$ knockouts is because of prolonged activation of JNK (Sakurai et al., 2006; Sun \& Karin, 2008). NF-אB is crucial for innate immune defense against microbial infection (Hayden \& Ghosh, 2008; Vallabhapurapu \& Karin, 2009). However, there are several regulators including bacterial infections, which show autoimmune, innate and humoral immune responses by cytokines, interleukins and other regulators.
Conclusively, the roles played by NF- $\kappa \mathrm{B}$ (Fig. 2) in autoimmunity, drugs which target it and complexities which need to be addressed to improve the use of NF- $\kappa \mathrm{B}$ as a target has been described (O'Sullivan et al., 2007; Uwe, 2008). These facts support its master regulator activity. The immune system has evolved a variety of receptors to recognize invading microorganisms (pathogens, bacteria and viruses) which result activation of $\mathrm{NF}-\kappa \mathrm{B}$ trafficking by gene regulation reported by Rahman et al. (2011). In contrast, (Fig. 2) immune regulation by secreted pathogen derived proteins (NS3, gp350, Core) and viral coded proteins can induce TLR, TNFR and other receptors to activate MyDD88 and TAK1 (Rahman et al., 2011). It also upregulate the $\mathrm{I} \kappa \mathrm{B} \alpha$ and control the $\mathrm{NF}-\kappa \mathrm{B}$.

\section{ROLE OF miRNAs AS NOVEL CLINICAL BIOLOGICAL PLAYERS IN OS}

miRNAs play as mega diverse roles as tumor suppressors, oncogenes inducers or both in some cases (Davis \& Hata, 2009). These qualities of miRNAs keep them as essential multipurpose prognostic and diagnostic tools in various oncogenesis including OS (Kobayashi et al., 2012). Normally miRNAs are present in various parts of the body in the form of fluids as serum, plasma, saliva, urine and milk (Chen et al., 2008; Mitchell et al., 2008; Zhou et al., 2013). Abnormal levels of miRNA can cause and are tightly linked with cancers and diseases including OS (Chen et al., 2008; Mitchell et al., 2008; Zhou et al., 2013). Studies have demonstrated diverse genetic alterations in OS cells including structural abnormalities, gain and/or loss of chromosomes, mutation in tumor suppressor genes and epigenetic modifications (Kansara \& Thomas, 2007; Broadhead et al., 2011). OS is characterized by a high propensity for pulmonary metastasis. Novel therapeutic targets and approaches are required to suppress pulmonary metastasis of OS and improve prognosis which is a major cause of death (Longhi 
A New Paradigm to Mitigate Osteosarcoma by Regulation of MicroRNAs and Suppression of the NF-kB Signaling Cascade

et al., 2006). NF-кB can induce the synthesis of proteins that regulate miRNAs (Hoesel \& Schmid, 2013). Under normal conditions, overexpression of miRNA-194/192/215 induces the expression of p53 and p21 in OS cell lines. Furthermore, p53 dissociate from p53-specific E2 Ubiquitin protein ligase and is reported to arrest cell cycle and apoptosis to repair/damage cells (Kobayashi et al., 2012). The most important so far example is of NF- $\kappa \mathrm{B}$-dependent induction of Lin28, a protein which inhibits the processing and maturation of let-7 miRNAs. Further, members of let7 miRNA family are often down-regulated in cancer and which seems to act as tumor suppressor (Fig. 1). Iliopoulos et al. (2007) showed, Let-7 miRNAs target IL-6 thus a reduction of let-7 leads to higher levels of IL-6 and further activation of NF- $\mathrm{BB}$ generating a positive feedback loop.

Ghosh \& Karin (2002) revealed, mostly in neoplasm (OS), the NF- $\mathrm{kB}$ pathway is switched on by a variety of cellular, developmental signals and biological factors. In contrast, a study of metastases of osteogenic sarcoma has revealed that up-regulation of GSK-3 $\beta$ activity is directly and jointly involved in tumor progression and clonogenicity (Yin et al., 2013). Further it has been reported that cell survival in OS in which induction of blocking of GSK-3 $\beta$ down-regulates the function of NF- $\kappa$ B pathway genes and act as anti-tumorigenic through in-vitro and mouse models (Tang et al., 2012). Therefore, therapeutic targeting of GSK-3 $\beta$ mediated inhibition of NF- $\kappa$ B pathway could be novel strategy to overcome against OS in-vitro and in-vivo. Reports by Silverman \& Maniatis (2001) proved that the molecular mechanism of NF- $\mathrm{BB}$ signaling pathway between Drosophila and mammals is not fully understood but distinct signaling similarities are used by human and flies to activate their NF- $\kappa \mathrm{B}$ trafficking. In both cases they activate TLRs to initiate intracellular signaling cascades that gave the threshold to activation of $N F-\kappa B / R e l$ family transcription factors. In addition, insect activate NF-кB precursor Rel by IKK and caspase-dependent endoproteolytic cleavage while mammalian NF- $\kappa \mathrm{B}$ is activated by proteasome mediated destruction of I $\mathrm{B}$ B proteins on $\mathrm{N}$-terminal inhibitory domains of NF- $\kappa$ B precursor (p100 and p105). Further, Perkins (2007), Karin (2009) showed, Rel family proteins exist as hetro-homodimeric proteins that are segregated in cytoplasm by interaction with various members of I $\mathrm{KB}$ inhibitor family proteins. Studies conducted by Perkins (2007), Karin (2009) reported, that IאB proteins are influenced by many extracellular signals, responsible for destruction of I $\kappa \mathrm{B}$ inhibitor proteins by the activation of I $\mathrm{B}$ kinase of IKK. However, the number of enzymes inhibit the invasion and migration of tumor propagation by several miRNAs interference which suppressed the expression of fatty acid synthase (FASN) and reduced the expression level of pAKT, NF-кB (p65), matrix metalloproteinase-2 and 9 (MMP-2 and MMP-9) proteins in OS (Liu et al., 2013). Felx et al. (2006) showed, vice-versa action that Endothelin-1 (ET-1) promotes MMP-2 and MMP-9 induction involving the transcription factor NF- $\mathrm{BB}$ in human osteosarcoma.

\section{IMPORTANT SUPPRESSOR miRNAs IN OS}

There are several mRNAs which can ameliorate tumor progression and metastasis by gene silencing or other ways and mechanisms (Mendell \& Olson, 2012), that are required to know. In-vivo, injection of miRNA-143 down regulates proliferation and delayed tumor formation. Overexpression of miR-124 suppressed Rac1 protein expression and atenuated cell proliferation, migration, invasion and induced apotosis in MG-63 and U2OS in-vitro. Significant reduction in tumor size has been reported upon its transfer into MG63 and U-2 OS cell lines (Table 1). It also inhibits lung metastases in OS (Zhou et al., 2013). Tumor suppressor miRNA (miR-218) suppressed the expression level of $\mathrm{T}$ cell lymphoma invasion and metastasis 1 (TIAM1), MMP2, MMP-9. It also inhibits OS cell migration and invasion (Jin et al., 2013). Further, the ether-à-go-go 1 (Eag1) voltage- 
Table 1. Clinically important down-regulated miRNAs in OS

\begin{tabular}{|c|c|c|c|c|c|c|}
\hline miRNAs & $\begin{array}{l}\text { Analysis of samples with } \\
\text { respect to OS tissue and cell } \\
\text { lines }\end{array}$ & Putative function & $\begin{array}{l}\text { Chromosome } \\
\text { number }\end{array}$ & $\begin{array}{l}\text { Targets of } \\
\text { miRNA }\end{array}$ & Techniques used for validation & References \\
\hline $\begin{array}{l}\operatorname{miR}-199 a-3 p \\
\operatorname{miR}-127-3 p\end{array}$ & OS cell line vs osteoblast cells & $\begin{array}{l}\text { Inhibits cell growth, migration, } \\
\text { regulate cell cycle }\end{array}$ & $\begin{array}{l}19,14 \\
\text { respectively }\end{array}$ & mTOR, stat3 & Microarray, qRT-PCR & $\begin{array}{l}\text { Duan et al. } \\
\text { (2011) }\end{array}$ \\
\hline $\begin{array}{l}\text { miR-34 family } \\
(34 \mathrm{a}, 34 \mathrm{~b} \text {, and } \\
34 \mathrm{c})\end{array}$ & $\begin{array}{l}\text { OS cell line vs patients } \\
\text { samples }\end{array}$ & $\begin{array}{l}\mathrm{P}^{53} \text { dependent manner cell cycle } \\
\text { arrest and apoptosis }\end{array}$ & $\begin{array}{l}\quad 1,11 \\
\text { respectively }\end{array}$ & $\begin{array}{l}\text { CDK6, } \\
\text { E2F3, } \\
\text { CyclinE2, } \\
\text { Bcl-2 }\end{array}$ & $\begin{array}{l}\text { qRT-PCR, 3'UTR luciferase } \\
\text { reporter assay, FACS analysis, } \\
\text { DNA methylation assay }\end{array}$ & $\begin{array}{l}\text { He et al. (2009); } \\
\text { Wu et al. (2013) }\end{array}$ \\
\hline $\begin{array}{l}\text { miR-382, miR- } \\
134, \text { miR-369- } \\
3 p \text { and miR-544 }\end{array}$ & $\begin{array}{l}\text { OS vs normal bone, OS cell } \\
\text { line vs osteoblast }\end{array}$ & $\begin{array}{l}14 \mathrm{q} 32 \text { miRNAs decreased cMYC } \\
\text { levels and induced apoptosis }\end{array}$ & 14 & cMYC & $\begin{array}{l}\text { Microarray, qRT-PCR, } \\
\text { Western blot }\end{array}$ & $\begin{array}{l}\text { Thayanithy et al. } \\
\text { (2012) }\end{array}$ \\
\hline miR-143 & $\begin{array}{c}\text { OS patients tissue } \\
\text { sample,MG63 and U2OS cell } \\
\text { lines vs normal osteoblast and } \\
\text { HEK293 cell line }\end{array}$ & $\begin{array}{l}\text { miR-143 may exert its proapoptotic } \\
\text { function via inhibiting Bcl-2 } \\
\text { expression. }\end{array}$ & 5 & $\mathrm{Bcl} 2$ & $\begin{array}{c}\text { 3'UTR luciferase reporter assay, } \\
\text { qRT-PCR, Western Blot and } \\
\text { Tumorigenicity assay in nude } \\
\text { mice }\end{array}$ & $\begin{array}{l}\text { Zhang et al. } \\
\text { (2010) }\end{array}$ \\
\hline miR-145 & $\begin{array}{l}\text { Human OS tissues vs normal } \\
\text { bone } \\
\text { Tissues, MG63 vs ECV304 } \\
\text { cell lines }\end{array}$ & $\begin{array}{l}\text { miR-145 down regulate VEGF at } \\
\text { translational level by partially } \\
\text { binding to VEGF 3' UTR. }\end{array}$ & 5 & VEGF & $\begin{array}{c}\text { western blot, Cell adhesion assay, } \\
\text { Trans- well invasion assay, Endo- } \\
\text { thelial cell tube formation assay, } \\
\text { luciferase assay }\end{array}$ & Fan et al. (2012) \\
\hline miRNA-218 & $\begin{array}{l}\text { Human patient tissues vs } \\
\text { normal tissue and SaOS-2 cell } \\
\text { line }\end{array}$ & $\begin{array}{l}\text { miR-218 suppresses the proliferation, } \\
\text { migration and invasion of Saos-2 } \\
\text { cells in vitro by targeting TIAM1, } \\
\text { MMP2 and MMP9 genes. }\end{array}$ & 4 & $\begin{array}{l}\text { TIAM1, } \\
\text { MMP2 and } \\
\text { MMP9 genes }\end{array}$ & $\begin{array}{l}\text { quantitative RT-PCR, Wound } \\
\text { healing assay, Transwell assay, } \\
\text { ATPlite assay for cells } \\
\text { proliferation, and Western Blot }\end{array}$ & Jin et al. (2013) \\
\hline $\operatorname{miR}-133 b$ & $\begin{array}{l}\text { Primary OS tumor sample vs } \\
\text { Normal bone tissue and U2- } \\
\text { OS }\end{array}$ & $\begin{array}{l}\text { miR-133b decreased the expression } \\
\text { target genes BCL2L2, MCL-1, } \\
\text { IGF1R and MET regulate the } \\
\text { phospho-Akt and FAK signaling }\end{array}$ & 6 & $\begin{array}{l}\text { BCL2L2, } \\
\text { MCL-1, } \\
\text { IGF1R and } \\
\text { ME, p-Akt } \\
\text { and FAK }\end{array}$ & $\begin{array}{l}\text { qRT-PCR, FACS analysis, Cell } \\
\text { Proliferation Assay, Boyden } \\
\text { chamber assay, Western blotting } \\
\text { and Hierarchical cluster analysis }\end{array}$ & $\begin{array}{l}\text { Zhao et al. } \\
\text { (2013) }\end{array}$ \\
\hline $\operatorname{miR}-24$ & $\begin{array}{l}\text { Human OS vs non-cancerous } \\
\text { adjacent tissues, MG63, 143B } \\
\text { and hFOB1.19 }\end{array}$ & $\begin{array}{l}\text { Overexpression of miR-24 down- } \\
\text { regulated LPAATb expression in OS } \\
\text { cells. }\end{array}$ & 9 & LPAATb & $\begin{array}{l}\text { Immunofluorescence and } \\
\text { Immunohist. staining, } \\
\text { Computational analysis by } \\
\text { program:TargetScan5.1, qRT- } \\
\text { PCR analysis, Fluorescent } \\
\text { reporter assay, Cell viability } \\
\text { assay, FACS }\end{array}$ & $\begin{array}{l}\text { Song et al. } \\
\text { (2013) }\end{array}$ \\
\hline $\operatorname{miR}-16$ & $\begin{array}{c}\text { HOS, KHOS, U2OS, and MG- } \\
63 \text { vs HOB cell line and } \\
\text { Eighteen OS patient samples } \\
\text { vs normal tissues }\end{array}$ & $\begin{array}{l}\text { Overexpression of miR-16 } \\
\text { suppresses OS cell proliferation and } \\
\text { tumor growth by inhibition of Raf1- } \\
\text { MEK1/2-ERK1/2 pathway. }\end{array}$ & 13 & IGF1R & $\begin{array}{c}\text { Cell proliferation assay and cell } \\
\text { cycle analysis, Western blotting, } \\
\text { Tumor growth assay, luciferase } \\
\text { reporter assay, }\end{array}$ & $\begin{array}{l}\text { Chen et al. } \\
\text { (2013) }\end{array}$ \\
\hline miR-199b-5p & $\begin{array}{c}\text { Eight FFPE Patients vs } \\
\text { tissue samples, ES97, HS3.T, } \\
\text { SJSA-1, and } \\
\text { MG63 vs normal cell line }\end{array}$ & $\begin{array}{l}\text { Inhibition of Notch and HES1 } \\
\text { signaling by miR-199b-5p as a } \\
\text { potential therapeutic strategy to } \\
\text { prevent metastasis in human OS. }\end{array}$ & 9 & $\begin{array}{l}\text { HES1 and } \\
\text { Notch } \\
\text { signaling }\end{array}$ & $\begin{array}{c}\text { Microarray analysis and qRT- } \\
\text { PCR }\end{array}$ & $\begin{array}{l}\text { Won et al. } \\
\text { (2013) }\end{array}$ \\
\hline $\operatorname{miR}-124$ & $\begin{array}{l}\text { MG-63, U2OS, SOSP-9607, } \\
\text { and SAOS-2/ tissue samples } \\
\text { vs normal tissue and cell lines }\end{array}$ & $\begin{array}{c}\text { Overexpression of miR-124 } \\
\text { suppressed Rac1 protein expression }\end{array}$ & 8 & Rac1 & $\begin{array}{l}\text { TaqMan RT-PCR, Cell } \\
\text { proliferation and invasion assay, } \\
\text { Dual Luciferase assay, Rac1 } \\
\text { rescue assay and western blot. }\end{array}$ & $\begin{array}{l}\text { Geng et al. } \\
\text { (2014) }\end{array}$ \\
\hline
\end{tabular}

gated $\mathrm{K}^{+}$is a central nervous system (CNS) localized channel that overexpresses in number of cancer patients it expresses in $75 \%$ solid tumor. The overexpression of miR34a decreased the expression level of Eag1 in in-vitro (MG-63, SaOS-2 cell lines) and in-vivo in OS (Wu et al., 2013). Many miRNAs occurred in different chromosomes in various position but most prognostic miRNAs were located at 14q32 (Kelly et al., 2013). These loci are already associated with OS which predict chemoresponses with 75 to $80 \%$ accuracy without overlaping with prognostic profile. Zhang et al. (2010) showed, miR-143 named as 'targetome' can inhibits many targeted mRNAs (Bcl2, DNMT3A, KRAS, 
and ERK5) to regulate post transcription in OS and cancer development (Table 1). Duan et al. (2011) studied, miR199a-3p, miR-127-3p influence the mTOR, STAT3 that arrest cell cycle (Table 1). Next, He et al. (2009) and Wu et al. (2013) showed, miR-34 family jointly with CDK6, Cyclin E2, Bcl2 possess p53 dependent apoptosis in OS (Table 1). Thayanithy et al. (2012), reported that miRNAs (miR-382, miR-134, miR-369 and miR-544) arrest cell cycle and apoptosis via down-regulating the expression of c-Myc in OS (Table 1). 3'UTR silenced of VEGF by miR145 in OS (Table 1) that control the tumor progression (Fan et al., 2012). The miR-218 causes lesion the OS by targeting of TIAM1, MMP-2 and MMP-9 (Table 1) (Jin et al., 2013). B-cell lymphoma-2 (Bcl2) and insulin-like growth factor 1 receptor (IGF1R) down-regulate the miR-133b Akt pathway in OS (Zhao et al., 2013). The miR-24 suppressed the expression of LPAATb in OS (Song et al., 2013). In addition, MEK and ERK Pathway regulated via downregulation of Raf by miR-16 in OS (Chen et al., 2013). Won et al. (2013) revealed, HES1 is suppressed in OS by miR199b as an inhibitor in Notch signaling cascade (Table 1).

\section{NEOPLASIA PROMOTER miRNAs IN OS}

OS are complex bone tumors with various genomic alterations (Smida et al., 2010). Polygenic spectrum of germline risk factors pointing towards specific pathways as drivers of disease; it implicates 33 inherited risk loci in heritable dog osteosarcoma, including regulatory variants near CDKN2A/B (Karlsson et al., 2013). These alterations affect the expression and function of several genes by overexpressed miRNAs in OS patients (Namløs et al., 2012). Genomic alterations are also associated with several transcription factor (TF), co-regulate networks in OS cell proliferation (Poos et al., 2013). Some clinically candidate miRNAs (miR-196a and miR-196b) have been demonstrated to play a crucial role in normal cell differentiation, proliferation and in tumorgenesis of various cancer types (Table
1) including OS cell lines relative to normal bone (Namløs et al., 2012; Liu et al., 2013; Zhang et al., 2014). Another miR-33a is up-regulated in chemoresistant OS (Fig. 1). The level of miR-33a is negatively correlated with the TWIST protein level and the tumor necrosis rate in OS (Zhou et al., 2014). In addition, miR-33a promotes OS cell resistance to cisplatin by down-regulating TWIST. Actually, TWIST is a pivotal negative regulator of OS chemoresistance (Table 2). Several miRNAs are key of modulator specifically, 14q32 miRNAs are up-regulated upon osteoblast maturation while overexpression (Exogenous) of 14q32 miRNAs leads to reduction in cMYC protein by blocking miR-17-92 or cMYC depletion which induces apoptosis in OS (Thayanithy et al., 2012; Shimada, 2013). Invasiveness induced through miR-362 by induced nuclear translocation of p65 and inversely regulates the CYLD expression by binding its 3'untranslated region in Gastric cancer (Fig. 1) including OS (Xia et al., 2014). Dysfunctional NF- $\kappa$ B activity contributes to various human conditions, including autoimmune, inflammatory disorders and cancer by miR125a and miR-125b (Kim et al., 2012; Tan et al., 2012). It directly Inhibit tumor necrosis factor alpha-induced protein 3 (TNFAIP3) expression, down-regulate the $\mathrm{p} 38 \alpha$ via UV that elevates NF- $\mathrm{B}$ Activity in diffuse large B-cell lymphoma (DLBCL) and OS (Fig. 1). Won et al. (2013) showed, the expression of 10 miRNAs (HS-169, HS-29, miR-10b, miR-150, miR-199b-5p, miR-223, miR-338-3p, miR-451, miR891a and solexa-578-1915) has been reported to increase 10 -fold in OS as compared with normal controls by microarray analysis (Table 2). Ziyan et al. (2011) reported, potential regulation of RECK by miR-21; it is over expressed in OS.

\section{A BRIDGING AVENUE TO AMELIORATE ONCOGENESIS THROUGH miRNAs AND NF- $\kappa \mathbf{B}$}

The nuclear factor-KappaB (NF- $\mathrm{KB})$ pathway is conserved from fruit flies to humans and is a key mediator of in- 
Table 2. Clinically important up-regulated miRNAs in OS

\begin{tabular}{|c|c|c|c|c|c|c|}
\hline ? of miRNAs & $\begin{array}{l}\text { Analysis of samples with } \\
\text { respect to OS tissue and cell } \\
\text { lines }\end{array}$ & Putative function & $\begin{array}{c}\text { Chromosome } \\
\text { number }\end{array}$ & $\begin{array}{l}\text { Targets of } \\
\text { miRNA }\end{array}$ & $\begin{array}{l}\text { Techniques used for } \\
\text { validation }\end{array}$ & References \\
\hline $\begin{array}{l}\text { miR-17-92 } \\
\text { (miRNA-17, } \\
\text { miRNA-18a, } \\
\text { miRNA-19a, } \\
\text { miRNA-19b, } \\
\text { miRNA-20a, } \\
\text { and miRNA-92) }\end{array}$ & $\begin{array}{c}\text { Normal tissue samples vs } \\
\text { patients and (Saos2, U2OS vs } \\
\text { Normal cells }\end{array}$ & $\begin{array}{l}3 \text { 'UTR of cMYC contained binding } \\
\text { sites for any of the } 14 \mathrm{q} 32 \text {-associated } \\
\text { miRNAs and miR-17-92 and } \\
\text { induced c-MYC regulation. }\end{array}$ & $\begin{array}{c}13 \\
14 \mathrm{q} 32 \\
(\mathrm{C} 13 \mathrm{Orf} 25)\end{array}$ & $\mathrm{cMYC}$ & $\begin{array}{c}\text { FACS, Bluefuse microarray } \\
\text { software, Cell invasion and } \\
\text { migration assay, Array } \\
\text { comparative genome } \\
\text { hybridization, Osteoblast } \\
\text { differentiation assay, Western } \\
\text { blot. Luciferase reporter } \\
\text { assays, qRT-PCR, } \\
\text { Nucleofection of miRNA } \\
\text { mimics }\end{array}$ & $\begin{array}{l}\text { Thayanithy et al. } \\
\text { (2012); } \\
\text { Shimada, } \\
\text { (2013) }\end{array}$ \\
\hline miR-33a & $\begin{array}{l}\text { OS patients samples, Saos-2, } \\
\text { MG-63 vs normal tissue, cell } \\
\text { lines }\end{array}$ & $\begin{array}{l}\text { miR-33a is up regulated in } \\
\text { chemoresistant OS which inhibits } \\
\text { the TWIST- } 3 \text { untranslated region- } \\
\text { luciferase reporter activity and alter } \\
\text { the TWIST expression }\end{array}$ & 22 & TWIST & $\begin{array}{l}\text { miRNA microarray analysis, } \\
\text { qRT-PCR, Western blot } \\
\text { analysis, Luciferase assay, } \\
\text { Measurement of apoptosis by } \\
\text { TUNEL assay }\end{array}$ & Zhou et al. (2014) \\
\hline miR-362 & $\begin{array}{c}\text { Gastric cancer tissues and cell } \\
\text { lines vs normal tissue and cell } \\
\text { lines }\end{array}$ & $\begin{array}{l}\text { Induced nuclear translocation of p65 } \\
\text { and inversely regulate the CYLD } \\
\text { expression by binding its } 3^{\prime} \\
\text { untranslated region. }\end{array}$ & Xp11.23 & $\begin{array}{l}\text { CYLD and } \\
\text { p65 }\end{array}$ & $\begin{array}{l}\text { Colony assay, flow cytometry, } \\
\text { TUNEL assay, luciferase } \\
\text { reporter assay, fluorescent } \\
\text { immunostaining, Western } \\
\text { blotting and qRT-PCR }\end{array}$ & Xia et al. (2014) \\
\hline $\begin{array}{l}\text { MiR-125a and } \\
\text { miR-125b }\end{array}$ & $\begin{array}{l}\text { HCT116, OS and Human } \\
\text { keratinocyte cell lines vs } \\
\text { HEK293 cell lines }\end{array}$ & $\begin{array}{c}\text { MicroRNA-125b Up-regulation } \\
\text { Promotes Cell Survival by } \\
\text { Targeting p } 38 \alpha\end{array}$ & $14 q 32$ & $\begin{array}{l}\mathrm{p} 38 \alpha \\
\text { TNFAIP3, } \\
\text { and A20 }\end{array}$ & $\begin{array}{l}\text { Immunoblotting, Luciferase } \\
\text { Assay, EMSA, ChIP and Cell } \\
\text { Survival Assay }\end{array}$ & $\begin{array}{l}\text { Kim et al. (2012); } \\
\text { Tan et al. (2012) }\end{array}$ \\
\hline $\begin{array}{l}\text { miR- } 150, \text { miR- } \\
199 \mathrm{~b}-5 \mathrm{p}, \mathrm{miR}- \\
451 \text { and solexa- } \\
578-1915\end{array}$ & $\begin{array}{l}\text { ES97, HS3.T, SJSA-1, and } \\
\text { MG63 and patients tissue } \\
\text { samples vs normal cells }\end{array}$ & $\begin{array}{l}\text { miRNAs inhibitor showed a change } \\
\text { in expression of Notch downstream } \\
\text { targets }\end{array}$ & 9 & $\begin{array}{l}\text { Notch1, D111, } \\
\text { JAG1, HES1, } \\
\text { Dtx1 }\end{array}$ & $\begin{array}{c}\text { qRT-PCR, microarray } \\
\text { analysis }\end{array}$ & Won et al. (2013) \\
\hline
\end{tabular}

flammatory signaling (Minakhina \& Steward, 2006; OlarerinGeorge et al., 2013). Aberrant regulation of NF- $\kappa \mathrm{B}$ is reported to be associated with autoimmune diseases, chronic inflammation and cancers (Silverman \& Maniatis, 2001). It makes the NF- $\kappa \mathrm{B}$ pathway an attractive therapeutic target (Olarerin-George et al., 2013). NF- $\mathrm{B}$ is a transcriptional regulator consisting of reticuloendotheliosis ( $\mathrm{Rel}$ ) protein dimers that bind a DNA sequence motif known as $\kappa \mathrm{B}$ site (Karin, 2009). NF-kB activation is a result of underlying inflammation or the consequence of formation of an inflammatory microenvironment during malignant progression (Perkins, 2007; Karin, 2009). It has ability to up-regulate the expression of tumor promoting cytokines, such as IL-6 or STAT3 and survival genes, such as Bcl-XL (Perkins, 2007; Karin, 2009). The basic-helix-loop-helix (b-HLH) factor Twist-1 is reported as a new mediator of the protective function of $\mathrm{NF}-\kappa \mathrm{B}$ and it blocks PCD induced by chemotherapeutic drugs and TNF-alpha in NF- $\mathrm{BB}$-deficient cells (Pham et al., 2007). It is also essential to counter this PCD in cancer cells via dephosphorylation of BCl-2. Next,
Tan et al. (2012) showed, activation of NF- $\mathrm{kB}$ by UV is required for miR-125b induction in colon cancer and OS. Deregulated miR-143 in cancers including OS directly target $\mathrm{BCl} 2$ and anti-apoptotic molecule and regulate NF$\kappa B$ (Zhang et al., 2010). While, Chen et al. (2013) demonstrated the miR-16 inhibits the proliferation and metastasis of OS by targeting IGF1R and suppression of Raf-MEK1/2, ERK1/2 in nude mouse (Table 1). Geng et al. (2014) reported that Rac1 targeted by $\mathrm{miR}-124$ that attenuated the cell proliferation, invasion and metastasis in MG-63 U2OS cell lines. Similarly, miR-26b (Fig. 1) inhibited the expression of TAK1 and TAB3 by binding to their 3'-untranslated region in hapatocarcinoma cells (Zhao et al., 2014). Let-7 and miR-34 family directly suppress the IL-6, STAT3 and MMP-9 (Table 1) which down-regulate the Rel family subunits and palliate from carcinogenesis (He et al., 2009; Iliopoulos et al., 2009; Zhou et al., 2013). Although, these miRNAs can regulate not only NF- $\kappa B$ bio-molecular mechanism but also involve in various type of signaling pathways in neoplasia (Davis \& Hata, 2009). On the other 
hand, few cancer inducer miRNAs (miR-362, miR-125b) are reported to up-regulate the Rel protein expression in invasived and metastasized tumors (Fig. 1 \& Table 2) (Kim et al., 2012; Tan et al., 2012; Xia et al., 2014). Moreover, miR-33a, overexpression causes drug resistance in OS by targeting TWIST (Zhou et al., 2014). Apart from these miRNAs there are several another which are yet to be known. Notably, the targeted genes mediated activation of miRNAs represses the tumor proliferation and metastasization by novel approach to link between miRNAs and NF- $\kappa \mathrm{B}$ as a bridge model in cancer biology. Moreover, we studied the inverse correlation or vice-versa of miRNAs and several signaling key molecules including Rel family $(\mathrm{NF}-\kappa \mathrm{B})$ expression in a panel of neoplasm (OS) patientderived xenografts as well as in-vitro model. Finally, we show that this bridge model can be a step ahead to overcome the issue of drug resistance and it also suggests that miRNAs combine with NF- $\kappa \mathrm{B}$ could be involved in resistance to drug sensitivity of cancer stem cells and its inhibition may be exploited in target therapy protocols.

\section{CONCLUDING REMARKS}

Although many phosphorylation sites on NF- $\kappa \mathrm{B}$ proteins have been characterized, it is still unclear how these phosphorylations regulate the ability of such proteins to induce or to repress defined target genes. Self-renewing solid and soft cancer stem cells are the subject of intensive research, as these are the key factors responsible for perpetuating tumor existence, for treatment of resistance and relapse. Tumor-promoting inflammation has finally been recognized as one of the hallmarks of cancer. Carcinogenesis is a multistage process in the classical sequence of chemical carcinogenesis; tumor initiation is followed by tumor promotion. Human epidemiology and animal model studies indicate that chronic, smoldering inflammation may be a far more widespread ground for cancer development than the previous thoughts. At the same time, NF- $\kappa$ B activation, acting as one of the pillars of inflammation, may have a promoting role in most cancers. Twenty-five years after the discovery of $\mathrm{NF}-\kappa \mathrm{B}$, meager information is available about its signaling and transcriptional targets. Taming of NF- $\kappa \mathrm{B}$ activity still remains an important challenge for modern cancer biology. Appearance of IKK\& to act as an oncogenic protein through $\mathrm{NF}-\kappa \mathrm{B}$, yet is totally unclear whether and how this kinase promotes breast cancer stem cell expansion. Answers to all such thoughts might come by the knock-in experiments in which the combined approach of "bridge between NF-kB and miRNAs (BBNM)" is adopted. Use of mice for in-vivo phenotypic analysis may provide a powerful biological model to address the regulation of $\mathrm{NF}-\kappa \mathrm{B}$ protein activities by phosphorylation. Moreover, now it seems that aberrant regulation of NF- $\kappa B$ could also underlie different type of cancers along with autoimmune, metabolic and neuronal diseases. Recent development in research to find the mechanism of OS progression is not adequate although mixed-model genome wide association study (GWAS) of OS has demonstrated regions associated with tumor progression in dog breeds (Karlsson et al., 2013). This approach can be used to study the cancer progression and metastasis. Despite of the significant progress in the elucidation of the roles played by $\mathrm{NF}-\kappa \mathrm{B}$ in cancers including OS cancer stem cell expansion, some issues remain to be experimentally addressed. Candidate genes known to regulate embryonic stem cells and to be specifically induced through IKK $\alpha$ activation remain to be identified. Although tremendous advances have been made in characterizing the role of the IKK complex and NF- $\kappa \mathrm{B}$ subunits, as well as upstream modulators such as TRAFs and RIPs, but still facts about how these signaling modules affect non-NF- $\mathrm{B}$ pathways remain to be learnt. However, clear genetic proof of crosstalk between pathways is difficult to obtain as it is necessarily obfuscated by deficits in the main pathway in which a given signaling 
component functions. The same holds true for interpretation of the biological outcomes of deleting signaling molecules that may bridge NF- $\kappa \mathrm{B}$ to other pathways and several miRNAs which are responsible for key regulation of all biological processes. In this study, we have tried to correlate $\mathrm{NF}-\kappa \mathrm{B}$ and their all components with many miRNAs as "Bridge Model" to make novel and innovative approach to ameliorate the inflammatory, metabolic, neuronal, bacterial/ viral transmitted diseases and cancer. The application of $\mathrm{NF}-\kappa \mathrm{B}$ inhibitors in combination with miRNAs is expected to result in a more efficient killing of the cancer stem cells and a slower or less likely recurrence of cancer. Another important aspect is that inhibition of NF- $\kappa \mathrm{B}$ might target cancer not only directly by blocking anti-apoptosis mechanisms of malignant cells, but also indirectly by shifting macrophages from the tumor-tolerating M2-polarization stage to the tumor attacking M1-stage by neoplasia suppressor miRNAs.

\section{ACKNOWLEDGEMENTS}

This study was supported by the Basic Science Research Program of Avian Spermatogonial stem cells (SSCs) grant number 2014-1128 from National Research Foundation of Korea.

\section{REFERENCES}

Abbott DW, Wilkins A, Asara JM, Cantley LC (2004) The Crohn's disease protein, NOD2, requires RIP2 in order to induce ubiquitinylation of a novel site on NEMO. Curr Biol 14:2217-2227.

American Cancer Society OS: Overview (2013) Available: http://www.cancer.org/acs/groups/cid/documents/webc ontent/003069-pdf

Baker RG, Hayden MS, Ghosh S (2011) NF-кB, Inflammation, and metabolic disease. Cell Metab 13:11-22.
Baritaki S, Bonavida, B (2010) Viral infection and cancer: the NF-kappaB/Snail/RKIP loop regulates target cell sensitivity to apoptosis by cytotoxic lymphocytes. Crit Rev Immunol 30:31-46.

Beristain AG, Narala SR, Di Grappa MA, Khokha R (2012) Homotypic RANK signaling differentially regulates proliferation, motility and cell survival in osteosarcoma and mammary epithelial cells. J Cell Sci 125:943-955.

Broadhead ML, Clark JCM, Myers DE, Dass CR, Choong PFM (2011) The molecular pathogenesis of osteosarcoma: A review. Sarcoma 2011:1-12.

Chen F (2005) Is NF- $\mathrm{B}$ a culprit in type 2 diabetes? Biochem Biophys Res Commun 332:1-3.

Chen L, Wang Q, Wang GD, Wang HS, Huang Y, Liu XM, Cai XH (2013) MiR-16 inhibits cell proliferation by targeting IGF1R and the Raf1-MEK1/2-ERK1/2 pathway in osteosarcoma. FEBS Lett 587:1366-1372.

Chen X, Ba Y, Ma L, Cai X, Yin Y, Wang K, Guo J, Zhang Y, Chen J, Guo X, Li Q, Li X, Wang W, Zhang Y, Wang J, Jiang X, Xiang Y, Xu C, Zheng P, Zhang J, Li R, Zhang H, Shang X, Gong T, Ning G, Wang J, Zen K, Zhang J, Zhang CY (2008) Characterization of microRNAs in serum: a novel class of biomarkers for diagnosis of cancer and other diseases. Cell Res 18: 997-1006.

Davis BN, Hata A (2009) Regulation of MicroRNA Biogenesis: A miRiad of mechanisms. Cell Commun Signal $7: 1-22$.

Duan Z, Choy E, Harmon D, Liu X, Susa M, Mankin H, Hornicek F (2011) MicroRNA-199a-3p is down regulated in human osteosarcoma and regulates cell proliferation and migration. Mol Cancer Ther 10:1337-1345.

Esquela-Kerscher A, Slack FJ (2006) Oncomirs-microRNAs with a role in cancer. Nat Rev Cancer (4):259-269.

Fan L, Wu Q, Xing X, Wei Y, Shao Z (2012) MicroRNA145 targets vascular endothelial growth factor and inhibits invasion and metastasis of osteosarcoma cells. Acta Biochim Biophys Sin (Shanghai) 44:407-414. 
A New Paradigm to Mitigate Osteosarcoma by Regulation of MicroRNAs and Suppression of the NF-KB Signaling Cascade

Felx M, Guyot MC, Isler M, Turcotte RE, Doyon J, Khatib AM, Leclerc S, Moreau A, Moldovan F (2006) Endothelin1 (ET-1) promotes MMP-2 and MMP-9 induction involving the transcription factor NF- $\kappa \mathrm{B}$ in human Osteosarcoma. Clin Sci (Lond) 110:645-654.

Geng S, Zhang X, Chen J, Liu X, Zhang H, Xu X, Ma Y, Li B, Zhang Y, Bi Z, Yang C (2014) The tumor supperssor role of miR-124 in osteosarcoma. PLos one 9: e91566.

Ghosh S, Karin M (2002) Missing pieces in the NFkappaB puzzle. Cell 109:S81-96.

Hayden MS, Ghosh S (2008) Shared principles in NF-кB signaling. Cell 132:344-362.

He C, Xiong J, Xu X, Lu W, Liu L, Xiao D, Wang D (2009) Functional elucidation of MiR-34 in osteosarcoma cells and primary tumor samples. Biochem Biophys Res Commun 388:35-40.

Hoesel B, Schmid JA (2013) The complexity of NF-kB signaling in inflammation and cancer. Mol Cancer 12: $1-15$.

Huxford T, Ghosh G (2009) A structural guide to proteins of the NF-kappaB signaling module. Cold Spring Harb Perspect Biol 1:1-16.

Iliopoulos D, Hirsch HA, Struhl K (2009) An epigenetic switch involving NF- $\kappa \mathrm{B}$, Lin28, Let-7 MicroRNA, and IL6 links inflammation to cell transformation. Cell 139: 693-706

Jin J, Cai L, Liu ZM, Zhou XS (2013) MiRNA-218 inhibits OS cell migration and invasion by downregulating of TIAM1, MMP2 and MMP9. Asian Pac J Cancer Prev 14:3681-3684.

Kaltschmidt B, Kaltschmidt C (2009) NF- $\kappa$ B in the nervous system. Cold Spring Harb Perspect Biol 1:113.

Kaltschmidt B, Widera D, Kaltschmidt C (2005) Signaling via NF-kappaB in the nervous system. Biochim Biophys Acta 1745:287-299.
Kansara M, Thomas DM (2007) Molecular pathogenesis of osteosarcoma. DNA Cell Biol 26:1-18.

Karin M (2009) NF-kappaB as a critical link between inflammation and cancer. Cold Spring Harb Perspect Biol 1:1-14.

Karlsson EK, Sigurdsson S, Ivansson E, Thomas R, Elvers I, Wright J, Howald C, Tonomura N, Perloski M, Swofford R, Biagi T, Fryc S, Anderson N, Courtay-Cahen C, Youell L, Ricketts SL, Mandlebaum S, Rivera P, von Euler H, Kisseberth, WC, London CA, Lander ES, Couto G, Comstock K, Starkey MP, Modiano JF, Breen M, Lindblad-Toh K (2013) Genome-wide analyses implicate 33 loci inheritable dog Osteosarcoma, including regulatory variants near CDKN2A/B. Genome Biol 14: $1-15$.

Kelly AD, Haibe-Kains B, Janeway KA, Hill KE, Howe E, Goldsmith J, Kurek K, Perez-Atayde AR, Francoeur N, Fan JB, April C, Schneider H, Gebhardt MC, Culhane A, Quackenbush J, Spentzos D (2013) MicroRNA paraffinbased studies in osteosarcoma reveal reproducible independent prognostic profiles at 14q32. Genome Med 5:112.

Kim SW, Ramasamy K, Bouamar H, Lin AP, Jiang D, Aguiar RC (2012) MicroRNAs miR-125a and miR$125 \mathrm{~b}$ constitutively activate the NF- $\kappa \mathrm{B}$ pathway by targeting the tumor necrosis factor alpha-induced protein 3 (TNFAIP3, A20). Proc Natl Acad Sci USA 109: 7865-7870.

Kobayashi E, Hornicek FJ, Duan Z (2012) MicroRNA involvement in osteosarcoma. Sarcoma 2012:1-8.

Li T, Guan J, Li S, Zhang X, Zheng X (2014) HSCARG downregulates $\mathrm{NF}-\kappa \mathrm{B}$ signaling by interacting with USP7 and inhibiting NEMO ubiquitination. Cell Death Dis 5:e1229.

Lin A, Liu ZG (2008) Cell signaling review series. Cell Res 18:327.

Lin SC, Wortis HH, Stavnezer J (1998) The ability of CD40L, but not lipopolysaccharide, to initiate immune- 
RK Mongre, SS Sodhi, M Ghosh, JH Kim, N Kim, N Sharma, DK Jeong

globulin switching to immunoglobulin G1 is explained by differential induction of NF-kappaB/Rel proteins. Mol Cell Biol 18:5523-5532.

Liu CJ, Tsai MM, Tu HF, Lui MT, Cheng HW, Lin SC (2013) MiR-196a overexpression and miR-196a2 gene polymorphism are prognostic predictors of oral carcinomas. Ann. Surg. Oncol 20:S406-S414.

Liu ZL, Mao JH, Peng AF, Yin QS, Zhou Y, Long XH, Huang SH (2013) Inhibition of fatty acid synthase suppresses osteosarcoma cell invasion and migration via downregulation of the PI3K/Akt signaling pathway in vitro. Mol Med Rep 7:608-12.

Longhi A, Errani C, De Paolis M, Mercuri M, Bacci G (2006) Primary bone OS in the pediatric age: state of threat. Cancer Treat Rev 32:423-436.

Mattson MP, Camandola S (2001) NF- $\kappa B$ in neuronal plasticity and neurodegenerative disorders. $\mathrm{J}$ of Clin Invest 107:247-254.

Mendell JT, Olson EN (2012) MicroRNAs in stress signaling and human disease. Cell 148:1172-1187.

Minakhina S, Steward R (2006) Nuclear factor-kappa B pathways in Drosophila. Oncogene 25:6749-6757.

Mitchell PS, Parkin RK, Kroh EM, Fritz BR, Wyman SK, Pogosova-Agadjanyan EL, Peterson A, Noteboom J, O'Briant KC, Allen A, Lin DW, Urban N, Drescher CW, Knudsen BS, Stirewalt DL, Gentleman R, Vessella RL, Nelson PS, Martin DB, Tewari M (2008) Circulating microRNAs as stable blood-based markers for cancer detection. Proc Natl Acad Sci USA 105:10513-10518.

Namløs HM, Meza-Zepeda LA, Barøy T, Østensen IH, Kresse SH, Kuijjer ML, Serra M, Bürger H, CletonJansen AM, Myklebost O (2012) Modulation of the Osteosarcoma expression phenotype by microRNAs. PLoS One 7:e48086.

National Institute of Health. (2014) Understanding Cancer Series - National Cancer Institute. Available: http://www. cancer.gov/cancertopics/understandingcancer/cancer/
O'Sullivan B, Thompson A, Thomas R (2007) NF- $\kappa$ B as a therapeutic target in autoimmune disease. Expert Opin Ther Targets 11:111-122.

Oeckinghaus A, Hayden MS, Ghosh S (2011) Crosstalk in NF-кB signaling pathways. Nature Immun 12:695-708.

Olarerin-George AO, Anton L, Hwang YC, Elovitz MA, Hogenesch JB (2013) A functional genomics screen for microRNA regulators of NF-kappaB signaling. BMC Biol 11:1-16.

Ougang L, Liu P, Yang S, Ye S, Xu W, Liu X, (2013) A three-plasma miRNA signature serves as novel biomarker for osteosarcoma. Med Oncol 30:340.

Papa S, Bubici C, Zazzeroni F, Franzoso G (2009) Mechanisms of liver disease: The crosstalk between the NF$\kappa \mathrm{B}$ and JNK pathways. Biol Chem 390: 965-976.

Perkins ND (2007) Integrating cell-signaling pathways with NF-kappaB and IKK function. Nat Rev Mol Cell Biol $8: 49-62$

Pham CG, Bubici C, Zazzeroni F, Knabb JR, Papa S, Kuntzen C, Franzoso G (2007) Upregulation of Twist1 by NF-kappaB blocks cytotoxicity induced by chemotherapeutic drugs. Mol Cell Biol 27:3920-3935.

Poos K, Smida J, Nathrath M, Maugg D, Baumhoer D, Korsching E (2013) How MicroRNA and transcription factor co-regulatory networks affect osteosarcoma cell proliferation. PLoS Comput Biol 9:1-13.

Pujari R, Hunte R, Khan WN, Shembade N (2013) A20mediated negative regulation of canonical NF- $\kappa \mathrm{B}$ signaling pathway. Immunol Res 57:166-171.

Rahman MM, McFadden G (2011) Modulation of NF- $\kappa$ B signaling by microbial pathogens. Nat Rev Microbiol 9:291-306.

Rieser E, Cordier SM, Walczak H (2013) Linear ubiquitination: a newly discovered regulator of cell signaling. Trends Biochem Sci 38:94-102.

Sakuda S, Tamura S, Yamada A, Miyagawa J, Yamamoto $\mathrm{K}$, Kiso S, Ito N, Higashiyama S, Taniguchi N, Kawata 
A New Paradigm to Mitigate Osteosarcoma by Regulation of MicroRNAs and Suppression of the NF-KB Signaling Cascade

S, Matsuzawa Y (2002) NF-kappaB activation in nonparenchymal liver cells after partial hepatectomy in rats: possible involvement in expression of heparinbinding epidermal growth factor-like growth factor. J Hepatol 36:527-533.

Sakurai T, Maeda S, Chang L, Karin M (2006) Loss of hepatic NF-kappa B activity enhances chemical heaptocarcinogenesis through sustained c-Jun N-terminal kinase 1 activation. Proc Natl Acad Sci USA 103: 10544-10551.

Shimada M (2013) MicroRNA-mediated regulation of apoptosis in osteosarcoma. J Carcinogene Mutagene S6:1-4.

Silverman N, Maniatis T (2001) NF- $\kappa B$ signaling pathways in mammalian and insect innate immunity. Genes Dev $15: 2321-2342$.

Smida J, Baumhoer D, Rosemann M, Walch A, Bielack S, Poremba C, Remberger K, Korsching E, Scheurlen W, Dierkes C, Burdach S, Jundt G, Atkinson MJ, Nathrath M (2010) Genomic alterations and allelic imbalances are strong prognostic predictors in Osteosarcoma. Clin Cancer Res 16:4256-4267.

Solt LA, Madge LA, Orange JS, May MJ (2007) Interleukin1 -induced NF- $\kappa \mathrm{B}$ activation is NEMO-dependent but does not require IKK. J Biol Chem 282:8724-8733.

Song L, Yang J, Duan P, Xu J, Luo X, Luo F, Zhang Z, Hou T, Liu B, Zhou Q (2013) MicroRNA-24 inhibits osteosarcoma cell proliferation both in vitro and in vivo by targeting LPAATb. Arch Biochem Biophys 535: 128-135.

Stiller CA (2007) International patterns of cancer incidence in adolescents. Cancer Treat Rev 33:631-645.

Sun B, Karin M (2008) NF- $\kappa$ B signaling, liver disease and hepatoprotective agents. Oncogene 27:6228-6244.

Sun SC (2011) Non-canonical NF-kB signaling pathway. Cell Research 21:71-85.
Tan G, Niu J, Shi Y, Ouyang H, Wu ZH (2012) NF-кBdependent microRNA-125b upregulation promotes cell survival by targeting $\mathrm{p} 38 \alpha$ upon UV radiation. J Biol Chem 287:33036-33047.

Tang QL, Xie XB, Wang J, Chen Q, Han AJ, Zou CY, Yin JQ, Liu DW, Liang Y, Zhao ZQ, Yong BC, Zhang RH, Feng QS, Deng WG, Zhu XF, Zhou BP, Zeng YX, Shen JN, Kang T (2012) Glycogen synthase Kinase-3 $\beta$, $\mathrm{NF}-\kappa \mathrm{B}$ signaling and tumorigenesis of human osteosarcoma. J Natl Cancer Inst 104:1-15.

Thayanithy V, Sarver AL, Kartha RV, Li L, Angstadt AY, Breen M, Steer CJ, Modiano JF, Subramanian S (2012) Perturbation of 14q32 miRNAs-cMYC gene network in osteosarcoma. Bone 50:171-181.

Uwe S (2008) Anti-inflammatory interventions of NF-кB signaling: Potential applications and risks. Biochem Pharmacol 75:1567-1579.

Vallabhapurapu S, Karin M (2009) Regulation and function of NF- $\kappa \mathrm{B}$ transcription factors in the immune system. Annu Rev Immunol 27:693-733.

Vigorita VJ (2008) Orthopaedic Pathology. Lippincott, Williams \& Wilkins, Philadelphia, PA, USA.

Wang CY, Mayo MW, Korneluk RG, Goeddel DV, Baldwin AS (1998) NF- $\kappa$ B antiapoptosis: induction of TRAF1 and TRAF2 and c-IAP1 and c-IAP2 to suppress caspase-8 activation. Science 281:1680-1683.

Won KY, Kim YW, Kim HS, Lee SK, Jung WW, Park YK (2013) MicroRNA-199b-5p is involved in the Notch signaling pathway in osteosarcoma. Hum Pathol 44: $1648-1655$

Wu CJ, Conze DB, Li T, Srinivasula SM, Ashwell JD (2006) Sensing of Lys 63-linked polyubiquitination by NEMO is a key event in NF-kappaB activation. Nat Cell Biol 8:398-406.

Wu X, Zhong D, Gao Q, Zhai W, Ding Z, Wu J (2013) MicroRNA-34a inhibits fuman osteosarcoma proliferation 
by downregulating ether à go-go 1 expression. Int $\mathrm{J}$ Med Sci 10:676-682.

Xia JT, Chen LZ, Jian WH, Wang KB, Yang YZ, He WL, He YL, Chen D, Li W (2014) MicroRNA-362 induces cell proliferation and apoptosis resistance in gastric cancer by activation of NF- $\mathrm{B}$ signaling. J Transl Med 12:1-12.

Yin JQ, Wen L, Wu LC, Gao ZH, Huang G, Wang J, Zou CY, Tan PX, Yong BC, Jia Q, Shen JN (2013) The glycogen synthase kinase-3 $\beta /$ nuclear factor-kappa $B$ pathway is involved in cinobufagin-induced apoptosis in cultured osteosarcoma cells. Toxicol Lett 218:129136.

Zhang C, Yao C, Haopeng L, Wang G, Xijng H (2014) Combined elevation of microRNA-196a and microRNA$196 \mathrm{~b}$ in sera predicts unfavorable prognosis in patients with OSs. Int J Mol Sci 15:6544-6555.

Zhang H, Cai X, Wang Y, Tang H, Tong D, Ji F (2010) MicroRNA-143, down-regulated in Osteosarcoma, promotes apoptosis and suppresses tumorigenicity by targeting Bcl-2. Oncol Rep 24:1363-1369.

Zhang L, Ding X, Cui J, Xu H, Chen J, Gong YN, Hu L, Zhou Y, Ge J, Lu Q, Liu L, Chen S, Shao F (2012)
Cysteine methylation disrupts ubiquitin-chain sensing

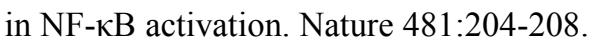

Zhao H, Li M, Li L, Yang X, Lan G, Zhang Y (2013) MiR-133b Is down-regulated in human OS and inhibits osteosarocma cells proliferation, migration and invasion, and promotes apoptosis. PLoS One 8:e83571.

Zhao N, Wang R, Zhou L, Zhu Y, Gong J, Zhuang SM (2014) MicroRNA-26b suppresses the NF- $\kappa B$ signaling and enhances the chemosensitivity of hepatocellular carcinoma cells by targeting TAK1 and TAB3. Mol Cancer 13:1-11.

Zhou G, Shi X, Zhang J, Wu S, Zhao J (2013) MicroRNAs in Osteosarcoma: From biological players to clinical contributors, a review. J Int Med Res 41:1-12.

Zhou Y, Huang Z, Wu S, Zang X, Liu M, Shi J (2014) MiR-33a is up-regulated in chemoresistant osteosarcoma and promotes osteosarcoma cell resistance to cisplatin by down-regulating TWIST. J Exp Clin Cancer Res $33: 12$.

Ziyan W, Shuhua Y, Xiufang W, Xiaoyun L (2011) Micro RNA-21 is involved in osteosarcoma cell invasion and migration. Med Oncol 28:1469-1474. 